\title{
Comparison of Aerodynamic Characteristics in Female Adults with Normal Function and with Functional Voice Disorders during Reading Paragraph Tasks
}

\author{
Hwa-Young Pyo \\ Department of Speech and Language Pathology, College of Health Sciences, Chosun University, Gwangju, Korea
}

정상 성인 여성 화자와 기능적 음성장애 성인 여성 화자의 문단 낭독 시 공기역학적 특성 비교

표 화 영

조선대학교 보건과학대학 언어치료학과

\begin{abstract}
Purpose: Aerodynamic characteristics of the patients with voice disorder should be evaluated not only in sustained vowel phonation but also in continuous speech production. This study was performed to compare aerodynamic characteristics during reading paragraph tasks in normal female adults and female adult patients with functional voice disorders. Methods: Fifty female adults with normal function and 50 female voice disorder patients participated in aerodynamic measurements during the reading paragraph. Among the results, 9 measurements were analyzed: total duration, number of inspiration, phonation time with voiced sounds, expiratory and inspiratory airflow duration, peak expiratory and inspiratory airflow, expiratory and inspiratory volume. Results: In all of the measurements, the patient group showed higher levels than the normal group. Seven measurements, excluding phonation time with voiced sounds and peak inspiratory airflow, showed significant differences between the two groups. Matching the total duration multiple regression analyses showed that $94.2 \%$ of the variance in the inspiratory volume was accounted by expiratory volume and number of inspiration, and $56.3 \%$ of peak expiratory airflow was done by peak inspiratory airflow. Conclusion: It was shown that the patient group used longer duration and higher airflow rate and volume in continuous speech compared to the normal group. We expect that aerodynamic evaluation and analysis in the continuous speech will help the valid assessment and intervention for the patients with voice disorders.
\end{abstract}

Key Words: Aerodynamic evaluation, Continuous speech, Reading paragraph tasks, Voice disorder patient.

Received: August 31, 2019 / Revised: October 3, 2019 / Accepted: October 6, 2019

Correspondence: Hwa-Young Pyo, Department of Speech and Language Pathology, College of Health Sciences, Chosun University, 309 Pilmun-daero, Dong-gu, Gwangju 61452, Korea

Tel: +82-62-230-6188 / Fax: +82-62-230-6172 / E-mail: entvoice@chosun.ac.kr

\section{INTRODUCTION}

음성은 폐에서 유입된 기류에 의해 성대가 진동을 반복함으 로써 형성된다(Mehta \& Hillman, 2008). 즉 음성은 폐에서 후 두로 공급되는 폐기류에 대한 반응으로 성대가 진동하여 산출 되는 음향적 결과물이다(Jiang \& Maytag, 2014). 음성산출 시

(c) This is an Open Access article distributed under the terms of the Creative Commons Attribution Non-Commercial License (https://creativecommons.org/licenses/by-nc/4.0) which permits unrestricted non-commercial use, distribution, and reproduction in any medium, provided the original work is properly cited.
성도는 여과기(filter)로 작용하며 이러한 음원-여과 상호작용 (source \& filter interaction)은 성문을 통과한 폐기류의 공기 역학 에너지가 음향 에너지로 전환되는 데 영향을 미친다. 이러 한 상호작용이 감소하면 음성의 경제성(vocal economy)도 감 소하며 이로 인해 평소와 같은 음성을 산출하기 위해 필요한 노력의 양이 증가하게 된다(Mills et al., 2017). 그러므로 장애 음성은 성대 자체뿐 아니라 호흡 체계와 성도 전체에 걸친 복합 적인 문제이며 성대 주변에서 일어나는 공기역학의 변화는 음 질의 지각과 음향적 변인들의 변화를 가져온다(Jiang \& May- 
tag, 2014). 따라서 장애음성을 평가하는 데 음성산출 시 동반 되는 공기역학의 변화를 파악하는 일은 중요하다. Espinoza et al.(2017)은 공기역학 측정은 성대 병리를 판단하는 데 음향적 측정보다 더 민감도가 높다고 했으며 Jiang \& Maytag(2014)은 공기역학적 특성이 성대의 생체역학 특성을 잘 반영하기 때문 에 음성을 평가할 때 매우 용이하다고 했다. 이 때문에 음성장 애 환자에 대한 공기역학적 평가는 임상적으로 매우 중요하다.

1980년대 이후 수십 년 동안 음성에 대한 공기역학 평가는 간 단한 음절어를 일정한 음도와 강도로 반복산출할 때 나타나는 성문하압과 성문기류를 비침습적으로 측정하는 것이 일반적이 었다(Mehta \& Hillman, 2008). 그러나 음성의 공기역학 측면에 대한 지식이 축적되고 이를 평가할 수 있는 과학적 발전이 동반 되면서 공기역학 평가에서도 지속적인 변화가 이루어지고 있다.

모음 연장이나 음절 반복을 통한 분석은 간편하고 문맥의 영 향을 받지 않는 장점이 있으나 일상생활에서 사용되는 공기역학 특성을 그대로 반영한다고 보기는 어렵다(Gerratt et al., 2016). 사람들은 발화 길이에 따라 발화 시 필요한 들숨과 날숨의 양 을 조절하기 때문에 모음 연장과 연속발화에서 사용하는 공기 역학 특성이 다르다는 것은 분명한 사실이다. 그러므로 일상생 활의 공기역학 특성을 파악하려면 모음 연장뿐 아니라 연속발 화의 분석 또한 필요하다. 이러한 요구에 맞추어 최근 문단 낭 독 시 공기역학 특성을 분석한 연구결과가 꾸준히 보고되고 있 다. Han et al.(2008)은 정상 성인의 문단 낭독 시 호흡 그룹의 특성에 대한 실험을 실시했고 Maryn \& Roy(2012)는 음성장애 환자를 대상으로 모음 연장과 문단 낭독 시 공기역학적 차이를 비교하였다. Pyo et al.(2014)은 정상 성인 및 음성장애 성인의 문단 낭독 시 호흡 단락에 대한 예비연구를 실시하였으며 Thiel et al.(2019)은 정상 성인을 대상으로 음절 산출과 문단 낭독 시 성문하압과 기류량을 비교하였다. 그러나 정상 성인과 음성장애 성인의 연속발화 시 기류량과 관련된 공기역학 측정치에 대한 비교연구는 국내는 물론 국외에서도 그 연구가 매우 부족하다. 공기역학적 평가의 궁극적 목적은 음성장애 환자 개인에 맞는 중재 계획 수립에 있으므로 무엇보다도 그 양상이 정상 범위에 포함되어 있는지, 정상 범위를 벗어나 있다면 얼마나 벗어나 있 는지 파악하는 것이 중요하다. 이를 적절히 판단하기 위해서는 정상 성대를 가진 정상 화자와 음성장애 환자가 어떤 차이를 보 이는지부터 파악해야 한다.

이에 본 연구에서는 정상 성대를 가진 정상 성인 여성 화자 와 기능적 음성장애를 진단받은 음성장애 성인 여성 환자의 문 단 낭독을 통한 연속발화 시 공기역학적 특성을 알아보고자 하 였다. 그 측정치를 비교해 보고 두 집단의 차이를 파악함으로 써 음성장애 환자의 평가 및 음성산출 개선을 위한 중재 시 활 용할 수 있는 기초 자료를 제공하고자 한다.

\section{MATERIALS AND METHODS}

\section{연구 대상}

본 연구의 참여자는 18 45세의 성인 여성으로 정상 성대를 가진 화자 50명과 기능적 음성장애(functional voice disorder)로 진단받은 음성장애 환자 50 명을 대상으로 하였다. 여성 화자에 한정한 이유는 발화 시 공기역학 특성은 성별에 따라 다르게 나 타나며(Lewandowski et al., 2018) 기능적 음성장애의 주된 원 인인 음성외상(phonotrauma)은 여성에게서 더 많은 빈도로 발 생하므로(Espinoza et al., 2017) 성별은 여성으로 한정하였다. 연령의 상한선을 45세로 선정한 이유는 Kim et al.(2003)의 연 구에서 우리나라 성인 여성의 평균 폐경 연령은 48.29 세이며 45 세 이상의 여성에게서 주로 나타났다는 보고에 따른 것이다.

정상 성인 여성을 대상으로 한 정상군과 음성장애 성인 여성 을 대상으로 한 환자군의 대상자 선정 시 공통적인 제외기준은 1) 실험 전 2시간 이내 흡연을 했거나 음성을 과하게 사용한 사 람, 2) 실험 당시 호흡기 질환, 알레르기성 비염, 감기 등 음성산 출에 영향을 미칠 만한 질환을 동반한 사람, 3) 음성산출에 영 향을 미치는 것으로 알려져 있는 약물(예, 혈압 강하제, 항응혈 제, 중추신경 자극제, 항역류성 약물 등)을 복용하고 있는 사 람, 4) 문단을 스스로 낭독할 수 있는 읽기능력 및 시력(교정 시 력 포함)을 갖지 못한 사람이다.

정상군의 선정기준은 1) 실험 당시 음성 문제가 없다고 보고 하고 10 년 이상의 숙련된 음성장애 전문가 2 인이 정상 음성을 산출한다고 판단한 사람, 2) 최근 6개월 이내 음성 문제로 병원 에 내원한 이력이 없는 사람이었다. 환자군의 선정기준은 1) 이 비인후과 전문의가 기능적 음성장애를 동반하고 있다고 진단 한 음성장애 환자, 2) 음성장애 진단을 받은 후 실험 당시 이를 치료하기 위한 약물치료, 수술치료, 음성치료를 받지 않은 환자 로 하였다.

정상군 50 명의 평균연령은 $23.54 \pm 7.14$ 세(18 42세)였고 환 자군 50명의 평균연령은 $33.48 \pm 7.40$ 세(18 44세)였다. 환자 군에 포함된 환자들의 GRBAS 척도 중 $\mathrm{G}$ 척도 평균은 중등도 (moderate)에 해당되는 $2.06 \pm 0.71$ 이었다. 이들이 동반한 진 단명은 성대용종(vocal polyp, 22명), 성대결절(vocal nodules, 17명), 근긴장성 발성장애(muscle tension dysphonia, 7 명), 만 성후두염(chronic laryngitis, 2명)이었고 성대결절 및 성대용종 이 동반된 경우가 2명이었다.

\section{연구 절차}

실험에 사용된 기자재는 발화 시 공기역학적 특성을 측정하 는 데 사용되는 Phonatory Aerodynamic System (PAS, model No. 6600, KayPENTAX Co., Montvale, NJ, USA)으로 이중 
연속발화 시 기류량, 지속 시간, 기류 체적에 대한 측정치를 제 공해주는 Running Speech 기능을 이용하였다.

연구 참여자들이 낭독한 발화 자료는 Kim(1996)의 '가을' 문 단 중 일부로 총 210 음절로 구성되었다. 이 낭독 자료는 A4 용 지에 글씨 크기 17 포인트, 줄 간격 $250 \%$, 가로 인쇄로 출력한 후 코팅하여 연구 참여자들에게 제공되었다. 낭독 자료의 전체 내용은 Appendix에 제시하였다.

실험은 대학 내 음성분석실에서 조용한 시간에 이루어졌다. 연구 참여자에게 낭독 자료를 주고 눈으로 한번 읽어보도록 하 여 낭독 시 실수를 줄이고자 하였다. PAS의 검사용 마스크를 양손으로 잡아 얼굴에 밀착시킨 후 평상 시 음도, 강도 및 말 속 도로 낭독 자료를 읽도록 하였다. 이때 낭독 자료는 검사자가 참 여자의 눈높이에 제시해 주었다. 전체 녹음 시간은 대략 45초 안 팎이었다. 문단 낭독 중 잘못 읽거나(예, '짝지어 있는 듯한'을 '짝 지어져 있는 듯한'으로 읽음) 갑자기 멈추거나(예, 산... 등성이를 따라') 음절을 반복하는(예, '될, 될 것만 같다') 등 비유창성이 3회 이상 나타날 경우 1 분 정도 휴식 후 다시 한 번 읽도록 하였다.

\section{자료 및 통계 분석}

최종 분석 자료는 문단 낭독 중 2회 이하의 비유창성이 나타 나는 경우로 하였고, 다시 읽어도 3회 이상의 비유창성이 나타 난 발화 자료는 분석에서 제외하였다. 이 과정을 거쳐 정상군, 환자군 각각 50 명, 총 100 명의 분석 자료를 확보하였다.

문단을 낭독하고 나면 화면에 Figure 1,2 와 같은 그림이 제 시된다. Figure 1 은 정상군의, Figure 2 는 환자군의 문단 낭독 후 화면이다. 그림은 세 개 창(window)으로 나뉘는데 첫 번째 창에서는 음도(pitch), 두 번째 창에서는 음압(sound pressure), 세 번째 창에서는 기류량(airflow)이 실시간으로 변화하는 양 상을 보여주고 있다. 세 번째 창에서 기류량이 $0 \mathrm{~L} / \mathrm{sec}$ 인 선을 기준으로 위에 나타나는 곡선은 호기가, 아래에 나타나는 곡선 은 흡기가 일어나는 부분이다. 이를 통해 호기 및 흡기가 일어 난 부분을 쉽게 관찰할 수 있다.

음도, 음압 및 기류량의 변화 곡선이 시작하는 지점과 끝나 는 지점을 전체 발화 구간으로 지정한 후 분석을 하면 총 10 개 의 측정치가 제공된다. 이중 최대 음압(maximum SPL), 평균 음도(mean pitch), 음도 범위(pitch range)를 제외한 7개 측정

Figure 1. Running Speech display after normal female's paragraph reading.
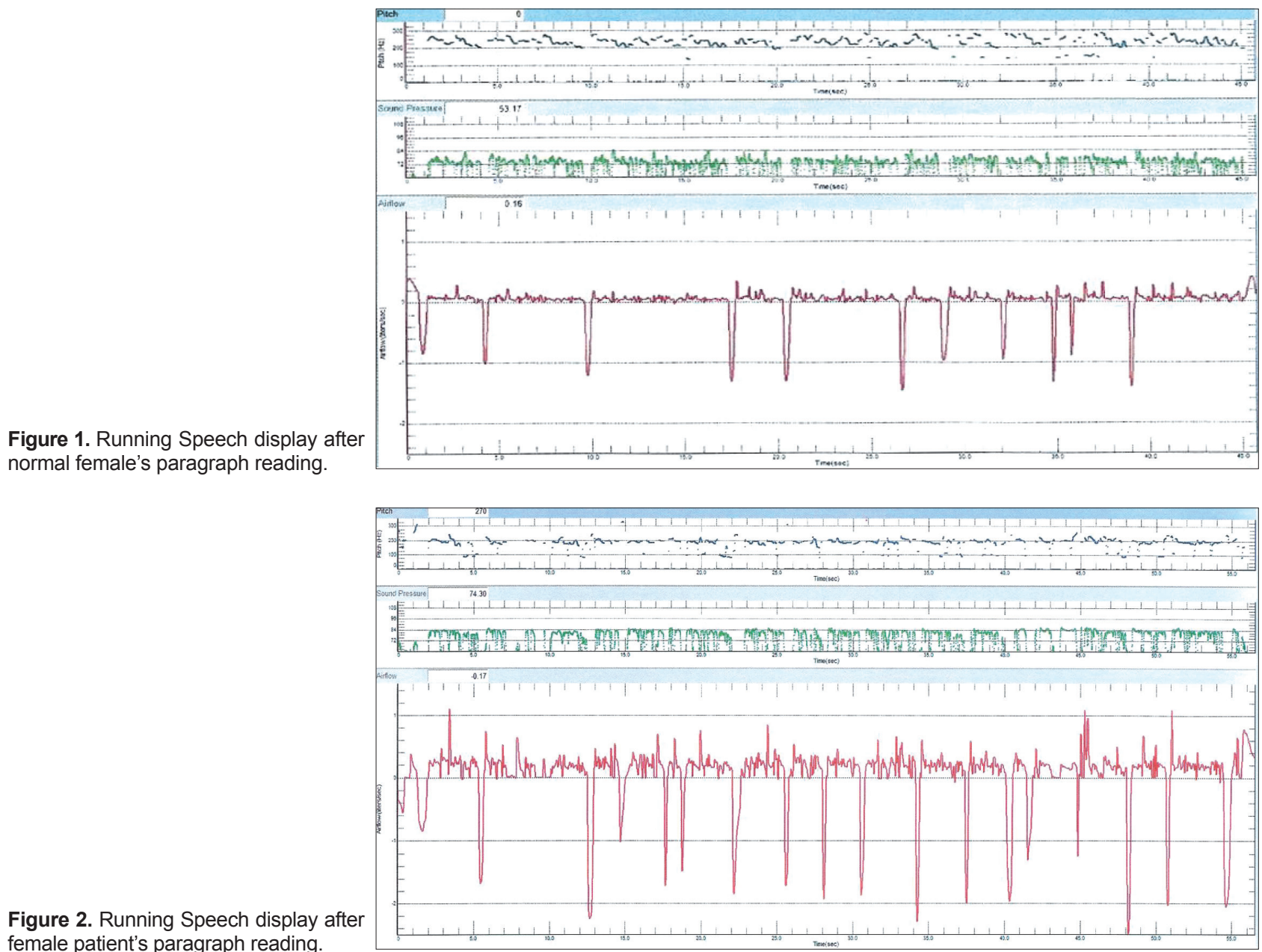
치를 공기역학 특성을 반영하는 측정치로 하였다. 그 7개 측정 치는 발화지속시간(phonation time, PT), 호기 및 흡기 지속 시 간(expiratory \& inspiratory airflow duration), 최대 호기 및 흡기량(peak expiratory \& inspiratory airflow), 호기 및 흡기 체적(expiratory \& inspiratory volume)이다. 발화지속시간은 전체 발화 구간 중 성대 진동과 더불어 산출된 시간을 의미하 며 호기지속시간은 전체 구간 중 기류량이 양의 값을 보이는 구간이고 흡기지속시간은 음의 값을 보이는 구간이다. 최대 호 기량 및 최대 흡기량은 각각 호기 구간 및 흡기 구간 중 가장 높게 나타난 공기량을 나타내고 호기 및 흡기 체적은 각각 전 체 호기 및 흡기에 사용된 공기 총량을 의미한다.

$\mathrm{PAS}$ 가 자체적으로 분석하는 7개 측정치 외에 총 발화지속 시간(total duration)과 흡기 횟수(number of inspiration)도 측 정하였다. 총 발화지속시간은 호기지속시간과 흡기지속시간의 합을 의미하는데 전체 발화 구간 중 성대 진동과 더불어 산출 된 시간만을 계산하는 발화지속시간(PT)보다 더 포괄적인 개 념이다. 총 발화지속시간과 구분하기 위해 발화지속시간은 이 후 '유성 발화지속시간(PT-voiced)'으로 표기하기로 한다. 흡기 횟수는 전체 발화 구간 중 흡기가 나타난 횟수로 기류량이 음 의 값을 보인 구간의 횟수를 의미한다. Figure 1 은 흡기 횟수가 10 회, Figure 2는 17회가 나타난 예를 보여준다. Figure 1이나 2 를 보면 -0.1 혹은 -0.2 Liter 이하의 미약한 흡기도 소수 관찰 된다. Han et al.(2008), Gartner-Schmidt et al.(2015) 등의 선 행문헌에서는 현저히 나타난 흡기만 횟수에 포함시켰으므로 본 실험에서도 0.2 Liter 이하의 미약한 흡기는 흡기 횟수에 포 함시키지 않았다.

이러한 과정을 거쳐 구해진 9개 측정치는 SPSS (Ver. 25.0, IBM Corp., Armonk, NY, USA)를 사용하여 각각의 평균 및 표준편차를 구하였다. 각 측정치에서 나타나는 정상군 및 환자 군 차이의 유의성은 독립표본 $t$ 검정을 통해 검증하였다. 다양 한 분석결과 9 개 측정치 중 영향력이 있는 변수로 판단되는 측
정치는 다중회귀분석을 이용하여 그 설명력과 영향을 미치는 주요 변수를 검증하였다.

\section{RESULTS}

정상군 및 환자군의 문단 낭독 시 공기역학 측정치에 대한 분 석결과를 Table 1에 제시하였다.

9개의 측정치 모두 정상군보다 환자군의 수치가 더 높게 나 타났다. 즉 음성장애 화자는 정상 화자보다 더 긴 총 발화지속 시간, 유성 발화지속시간, 호기 및 흡기 지속시간을 보였고 정 상 화자보다 더 많은 흡기 횟수, 더 큰 최대 호기량과 최대 흡기 량, 호기 체적과 흡기 체적을 보였다. 이를 정리하면 환자군은 정상군보다 더 긴 지속 시간, 더 잦은 흡기와 더 많은 기류를 사 용하는 것으로 나타났다.

정상군과 환자군이 보이는 평균 차의 유의성은 9 개 측정치 중 7개 측정치에서 유의한 것으로 나타났다. 총 발화지속시간, 흡기 횟수, 호기 및 흡기 지속시간, 최대 호기량, 호기 및 흡기 체적에서는 환자군이 정상군보다 유의하게 높은 수치를 보였 다. 그러나 유성 발화지속시간과 최대 흡기량에서 환자군이 보 인 더 높은 수치는 통계적으로 유의한 차이는 아니었다.

환자군의 참여자는 대체로 정상군 참여자보다 더 빈번한 흡 기 횟수를 보였고 흡기 체적도 더 높았으나 최대 흡기량은 정상 군과 유사하게 나타났다. 이러한 예는 Figure 3에서 그 예시를 볼 수 있다. 여기서 해당 환자는 15 회의 흡기 횟수를 보여 환자 군 평균인 11.68회보다 더 빈번한 흡기를 보였으며 빈번한 흡기 로 인해 흡기 체적도 -11.81 Liters로 환자군의 평균치인 -5.29 Liters보다도 훨씬 높은 수치를 보였다. 그러나 최대 흡기량은 $-1.92 \mathrm{~L} / \mathrm{sec}$ 로 정상군의 평균인 $-1.82 \mathrm{~L} / \mathrm{sec}$ 와 비슷하게 나타 났다.

총 발화지속시간 중 흡기지속시간과 호기지속시간의 비율이 차지하는 비율을 비교한 결과 정상군의 경우 1 대 4.72 였고 환

Table 1. Results of aerodynamic measurement during paragraph reading

\begin{tabular}{lcccc}
\hline \multicolumn{1}{c}{ Measures } & Normals $(\mathrm{n}=50)$ & Patients $(\mathrm{n}=50)$ & $t$ & \multicolumn{1}{c}{$p$-value } \\
\hline TD (sec) & $39.78(24.82)$ & $42.68(29.73)$ & $-2.779^{\dagger}$ & 0.007 \\
NI (number) & $10.20(8.83)$ & $11.68(8.79)$ & $-2.222^{*}$ & 0.029 \\
PT-voiced (sec) & $27.68(11.47)$ & $28.80(11.34)$ & -1.665 & 0.099 \\
EAD (sec) & $32.83(12.63)$ & $34.62(16.63)$ & $-2.335^{*}$ & 0.022 \\
IAD (sec) & $6.95(3.19)$ & $8.06(4.69)$ & $2.813^{\dagger}$ & 0.006 \\
PEA (L/sec) & $0.56(0.03)$ & $0.75(0.10)$ & $-3.656^{\ddagger}$ & 0.000 \\
EV (Liters) & $4.01(2.64)$ & $5.37(9.62)$ & $-2.742^{\dagger}$ & 0.007 \\
PIA (L/sec) & $-1.82(0.10)$ & $-2.01(0.43)$ & 1.855 & 0.067 \\
IV (Liters) & $-3.67(1.59)$ & $-5.29(5.84)$ & $4.208^{\ddagger}$ & $5.72015 \mathrm{E}-05$ \\
\hline
\end{tabular}

Values are mean (standard deviation). ${ }^{*} p<0.05,{ }^{\dagger} p<0.01,{ }^{\ddagger} p<0.001$. TD: total duration, NI: number of inspiration, PT-voiced: phonation time-voiced, EAD: expiratory airflow duration, IAD: inspiratory airflow duration, PEA: peak expiratory airflow, EV: expiratory volume, PIA: peak inspiratory airflow, IV: inspiratory volume 
Figure 3. Example of an voice disorder patient's paragraph reading with frequent inspiration.

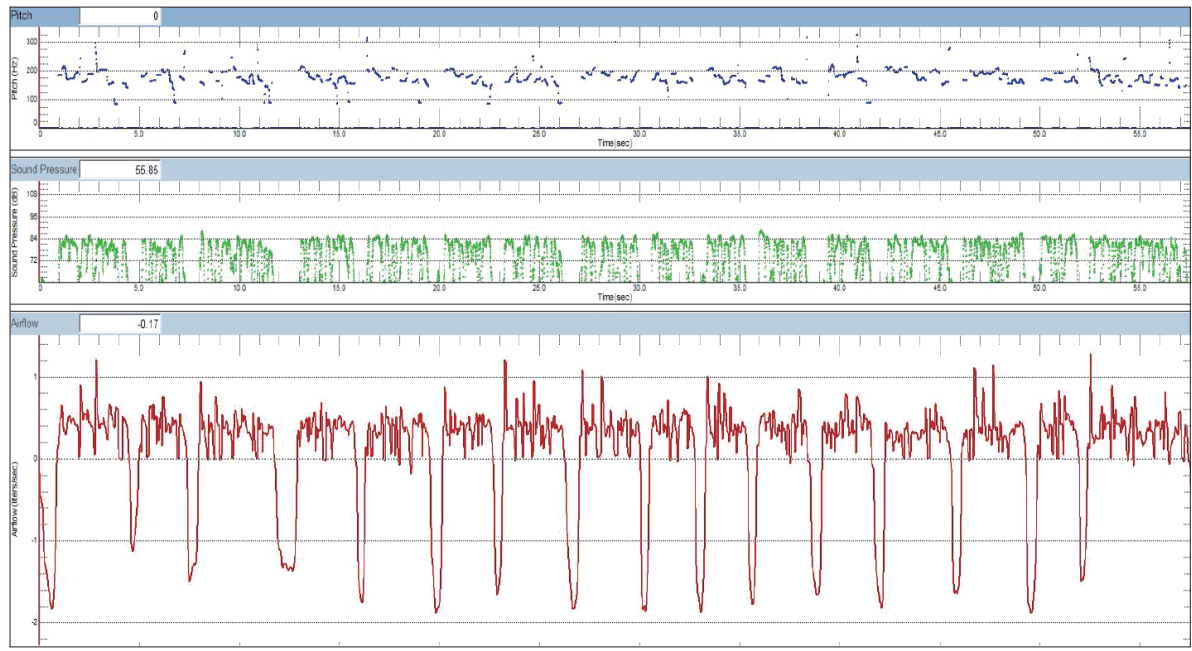

Table 2. Results of aerodynamic measurement during paragraph reading (matching TD)

\begin{tabular}{lcccc}
\hline \multicolumn{1}{c}{ Measures } & Normals $(\mathrm{n}=20)$ & Patients $(\mathrm{n}=20)$ & $t$ & 0.958 \\
TD $(\mathrm{sec})$ & $37.47(0.76)$ & $37.95(4.31)$ & 1.371 & 0.344 \\
NI (number) & $8.95(3.73)$ & $9.88(4.86)$ & -0.953 & 0.179 \\
PT-voiced (sec) & $26.58(1.80)$ & $27.08(3.85)$ & 0.026 & 0.347 \\
EAD (sec) & $31.49(0.86)$ & $31.50(5.28)$ & 1.402 & 0.979 \\
IAD (sec) & $5.98(0.94)$ & $6.44(1.28)$ & $2.622^{*}$ & 0.169 \\
PEA (L/sec) & $0.54(0.02)$ & $0.71(0.06)$ & 1.100 & 0.013 \\
EV (Liters) & $3.76(1.23)$ & $4.47(6.88)$ & -1.692 & 0.278 \\
PIA (L/sec) & $-1.83(0.08)$ & $-2.11(0.48)$ & $-2.254^{*}$ & 0.099 \\
IV (Liters) & $-3.33(0.45)$ & $-4.32(3.43)$ & 0.030 \\
\hline
\end{tabular}

Values are mean (standard deviation). ${ }^{*} p<0.05$. TD: total duration, NI: number of inspiration, PT-voiced: phonation time-voiced, EAD: expiratory airflow duration, IAD: inspiratory airflow duration, PEA: peak expiratory airflow, EV: expiratory volume, PIA: peak inspiratory airflow, IV: inspiratory volume

자군은 1 대 4.30 으로 환자군의 호기지속시간 비율이 정상군보 다 더 짧은 것으로 나타났다. 이러한 차이는 앞서 제시된 Figure 1 과 2에서도 관찰할 수 있다.

정상군과 환자군의 총 발화지속시간의 평균은 각각 39.78 초 와 42.68초로 그 차이는 유의수준 0.001 수준에서 유의한 것으 로 나타났다. 본 실험에서 문단을 읽는 속도에는 특별한 제한 을 두지 않고 평상시처럼 편안한 속도로 읽도록 했기 때문에 총 발화지속시간은 화자 개인의 특징적인 말 속도가 반영되어 있다. 문단 낭독 등 연속발화를 이용하여 기기적 분석을 할 때 에는 항상 말 속도 등 개인마다 다르게 나타나는 특성들을 어 떻게 통제할 것인가의 문제가 대두된다. 그러나 화자마다 서로 다른 말 속도를 통제하기 위해 개인차를 배제하고 비슷한 말 속도로 읽게 하는 것은 부자연스러운 발화를 유도하게 되고 이 는 결국 화자의 말 특성을 정확히 파악하지 못하게 한다. 이에 본 실험에서는 두 집단의 총 발화지속시간의 평균이 일치하도 록 집단을 재구성했을 때의 공기역학 측정치를 분석, 비교해 보 기로 하였다.
정상군 및 환자군 중 두 집단의 총 발화지속시간 평균 차가 독립표본 $t$ 검정 결과 유의하지 않도록 참여자를 구성한 결과 두 집단에서 각 20명씩 총 40 명이 선정되었다 $(t=0.958, p=0.344)$. 이 들이 보인 공기역학 측정치와 $t$-test를 통한 평균 차의 통계적 유의성을 Table 2에 제시하였다.

Table 2에서 보는 바와 같이 9개 측정치 모두에서 환자군의 측정치가 정상군의 측정치보다 높게 나타난 것은 말 속도를 일 치시키든 일치시키지 않든 같은 결과를 보였다. 그러나 그 차이 의 통계적 유의성은 다르게 나타났다. 말 속도를 일치시키지 않 았을 때는 9개 측정치 중 7개 측정치가 유의한 차이를 보였지 만 말 속도를 일치시켰을 때는 최대 호기량과 흡기 체적, 2 개 측정치의 차이만 유의한 것으로 나타났다.

이 결과를 바탕으로 말 속도를 일치시켰을 때와 일치시키지 않았을 때 모두 유의한 차이를 보인 최대 호기량과 흡기 체적을 종속변수로 하는 다중회귀분석을 실시하였다. 결과는 Table 3 과 4에 정리하였다.

최대 호기량을 종속변수로 한 회귀 모형은 통계적으로 유의 
Table 3. Multiple regression analysis results of PEA

\begin{tabular}{clccccc}
\hline Dependent variable & Independent variables & B & S.E. & $\beta$ & $t$ & $p$-value \\
\hline PEA & (Constant) & -0.002 & 0.110 & - & -0.020 & 0.984 \\
& Peak inspiratory airflow & -0.361 & 0.052 & $-0.750^{*}$ & -7.000 & 0.000 \\
\hline
\end{tabular}

${ }^{*} p<0.001 . \mathrm{F}=48.997(p=0.000), \mathrm{R}^{2}=0.563$, adj $\mathrm{R}^{2}=0.552$. PEA: peak expiratory airflow, S.E.: standard error

Table 4. Multiple regression analysis results of IV

\begin{tabular}{clccccc}
\hline Dependent variable & Independent variables & B & S.E. & $\beta$ & $t$ & 1.235 \\
\hline IV & (Constant) & 0.465 & 0.377 & - & 0.225 \\
& Expiratory volume & -0.703 & 0.032 & -0.891 & $-21.889^{*}$ & 0.000 \\
& Number of inspiration & -0.177 & 0.032 & -0.228 & $-5.607^{*}$ & 0.000 \\
\hline
\end{tabular}

${ }^{*} p<0.001 . \mathrm{F}=301.015(p=0.000), \mathrm{R}^{2}=0.942$, adj $\mathrm{R}^{2}=0.939$. IV: inspiratory volume, S.E.: standard error

한 것으로 나타났고 $(\mathrm{F}=48.997, p=0.000)$ 이 모형의 설명력은 약 56.3\%(수정된 R 제곱은 55.2\%)로 나타났다. 회귀계수의 유 의성을 검증한 결과 공기역학 측정치 중 최대 흡기량이 최대 호 기량에 유의한 영향을 미치는 것으로 나타났다.

흡기 체적을 종속변수로 하여 다중회귀분석을 실시한 결과 회귀 모형은 통계적으로 유의한 것으로 나타났고 $(\mathrm{F}=301.015$, $p=0.000$ ) 회귀 모형의 설명력은 약 $94.2 \%$ (수정된 $\mathrm{R}$ 제곱은 93.9\%)로 나타났다. 회귀계수의 유의성을 검증한 결과 공기역 학 측정치 중 호기 체적과 흡기 횟수가 흡기 체적에 유의한 영 향을 미치는 것으로 나타났다.

\section{DISCUSSIONS}

본 연구는 정상 성대를 가진 성인 여성 50명과 기능적 음성 장애를 진단받은 성인 여성 50 명의 문단 낭독을 통한 연속발화 시 공기역학적 측정치를 비교해 보고자 시행되었다. PAS의 Running Speech 프로그램을 이용하여 총 발화지속시간, 흡기 횟수, 유성 발화지속시간, 호기 및 흡기 지속시간, 최대 호기 및 흡기량, 호기 및 흡기 체적 등 9개 측정치를 분석하였다. 그 결 과 9 개 측정치 모두 환자군의 수치가 정상군보다 더 높았다. 9 개 측정치 중 유성 발화지속시간과 최대 흡기량은 그 차이가 통계 적으로 유의하지 않았고 다른 7개 측정치는 두 집단 간 차이가 유의한 것으로 나타났다. 총 발화지속시간 중 흡기지속시간과 호기지속시간의 비율을 비교한 결과 환자군은 1 대 4.30 , 정상 군은 1대 4.72로 정상군의 호기지속시간 비율이 더 높았다. 총 발화지속시간을 일치시켜 말 속도가 미치는 영향을 배제한 상 태에서 두 집단의 평균 차를 분석한 결과 9 개 측정치 중 최대 호기량과 흡기 체적에서만 유의한 차이가 나타났다. 이 결과를 바탕으로 두 측정치에 대한 다중회귀분석을 실시한 결과 흡기 체적은 호기 체적과 흡기 횟수가 $94.2 \%$ 를, 최대 호기량은 최대 흡기량이 $56.3 \%$ 를 설명하는 것으로 나타났다.

기능적 음성장애를 동반한 성인 여성 환자군은 정상 성대를
가진 성인 여성 정상군보다 전체적으로 더 긴 지속 시간을 보였 다. 환자군의 지속 시간이 더 긴 것은 정상군보다 흡기가 더 빈 번하게 나타난 데서 고찰해 볼 수 있다. 정상군의 흡기 횟수와 흡기지속시간은 평균 10.2회와 6.95초였고 환자군의 흡기 횟수 와 흡기지속시간은 평균 11.68 회와 8.06초였다. 이를 통해 초당 평균 흡기 횟수를 계산하면 정상군은 0.68 회, 환자군은 0.69 회 로 그 차이는 매우 적었다. 따라서 문단 낭독 시 발화지속시간 이 환자군에서 유의하게 더 길었던 것은 흡기의 시간보다 빈도 가 더 큰 영향을 미쳤을 것으로 판단할 수 있다. Lee \& Kim (2017)은 쉼(pause)은 말 속도(말 전체를 발화하는 데 걸리는 시 간)에 가장 큰 영향을 미치는 요인 중 하나로 심의 빈도 혹은 지속 시간에 따라 말 속도가 달라진다고 했다. 이에 비추어 보 면 음성장애 환자의 말 속도는 쉼의 시간보다 빈도의 영향을 더 받는 것으로 판단된다.

정상군 및 환자군의 흡기 및 호기 지속시간은 각각 6.95 초와 32.83초, 8.06초와 34.62초로 나타났다. 흡기 및 호기 지속시간 의 비율에 대한 선행연구는 Han et al.(2008)의 연구에서 찾아 볼 수 있다. 이들은 24 28세의 정상 성인 여성 20명을 대상으 로 문단 낭독 시 호흡 그룹 횟수를 측정하였는데 60 초 동안 흡 기 및 호기 시간의 비율이 일관적으로 약 1 대 5 로 나타났다고 했다. Han et al.(2008)의 연구에서 발화 자료의 낭독 시간은 60 초로 본 연구에서 사용한 길이보다 더 길었기 때문에 약간의 차이가 있으나 그 비율은 매우 비슷한 것으로 나타났다.

정상군과 환자군의 최대 호기 및 흡기량, 호기 및 흡기 체적 은 모두 환자군이 더 높은 수치를 보여 음성장애 환자가 정상 성인보다 더 많은 기류를 발화에 사용했음을 알 수 있었다. 대 부분의 음성장애 화자는 성대폐쇄의 비정상성을 동반한다 (Gartner-Schmidt et al., 2015). 본 연구에 참여한 음성장애 환 자는 대부분의 성대결절이나 성대용종, 만성후두염 등 성대폐 쇄부전을 동반한 환자들이었다. 성대폐쇄부전은 성문 사이를 통해 새어나가는 기류가 있기 마련이고 이로 인해 성대폐쇄부 전 환자들은 정상 성대를 가진 화자에 비해 높은 기류량을 보 
이는 것이 일반적이다.

Hillman et al.(1989)은 음성 과기능(vocal hyperfunction)을 동반하는 음성장애 환자들은 더 높은 후두근 긴장으로 인해 근육 활동의 불균형을 동반하는데 이 때문에 발성을 위해 더 큰 공기역학적 힘을 필요로 한다고 했다(as cited in Espinoza et al., 2017). 본 연구에 참여한 음성장애 환자들은 성대질환으 로 인해 발화 시 기류가 낭비되는 양상을 보이고는 있으나 호흡 기 기능은 정상이다. 그러므로 발성 시 정상군보다 더 많이 필 요한 기류량을 위해 더 높은 호기 및 흡기 체적을 확보할 수 있 었을 것이다. 만약 성대질환과 더불어 호흡기 기능에도 문제가 있었다면 충분한 기류량을 확보하지 못해 호기 및 흡기 체적은 더 낮아졌을 것이다. 그렇지만 정상군보다 더 많은 호기 및 흡 기 체적을 확보해야 한다는 부담은 호흡기 및 후두근육의 피로 를 동반하게 되며 이는 다시 음성 피로로 이어져 결국 음성산 출 문제를 심화시키게 될 것이다.

분석결과 나타난 9 개 측정치 중 유성 발화지속시간과 최대 흡기량은 두 집단 간의 유의한 차이를 보이지 않았다. Gerratt et al.(2016)은 10명의 음성장애 화자를 대상으로 /i/, /a/, /u/ 3 개 모음을 연장했을 때와 연속발화에서 나타난 세 모음을 추 출하여 연장모음과 같은 길이로 연결했을 때의 음향적 특성을 비교하였다. 분석결과 연장모음과 연속발화의 음향적 특성은 유의한 차이가 없다고 보고했다. 이 결과를 통해 이들은 연장 모음과 연속발화의 차이는 성대 진동의 차이가 아니라 다양한 분절 및 음운적 맥락에 기인한다고 했다. 본 연구결과가 총 발 화지속시간, 호기 및 흡기 지속시간에서는 두 집단 간에 유의 한 차이가 나타났지만, 성대 진동을 동반한 지속 시간을 측정 한 유성 발화지속시간은 유의한 차이를 보이지 못한 것도 이를 통해 설명할 수 있다.

최대 흡기량에서 정상군과 환자군이 유의한 차이를 보이지 않은 것은 앞서 환자군이 정상군보다 더 많은 흡기 횟수를 보 였으나 1 회 흡기 시 지속 시간은 별다른 차이가 없었던 것과 같 은 맥락에서 설명할 수 있다. 두 집단군 모두 정상적인 호흡능 력을 갖고 있으므로 숨을 들이마시기 위한 시간에 큰 차이가 없 었다는 것은 그 시간 동안 들이마실 수 있는 기류량도 비슷했을 것으로 판단할 수 있다. 이러한 양상은 앞서 설명한 Figure 3에 서도 관찰된다. 이로 인해 환자군과 정상군의 최대 흡기량에서 유의한 차이가 나타나지 않은 것으로 보인다.

말 속도를 일치시켜 개인차가 미치는 영향을 배제했을 때를 가정하고 공기역학적 측정치를 분석한 결과, 환자군의 측정치 가 더 높았다는 것은 일치시키지 않았을 때와 같았으나 그 통계 적 유의성은 다르게 나타났다. 즉, 말 속도를 일치시키지 않았을 때는 9 개 측정치 중 7 개 측정치에서 유의성이 검증되었지만 일치 시켰을 때는 2 개의 측정치에서 통계적 유의성이 관찰되었다. 그
두 측정치는 최대 호기량과 흡기 체적이었는데 이들은 말 속도 를 일치시키지 않았을 때도 유의수준 0.001 에서 유의한 차이를 보였다. 즉 최대 호기량과 흡기 체적은 개인차를 반영하든 소거 시키든 비교적 일관적인 경향을 제공해 준다고 볼 수 있다. 이는 두 측정치를 종속변수로 하여 회귀 분석을 실시했을 때 그 회귀 모형이 통계적으로 유의한 결과를 보인 데에서도 알 수 있다.

문단 낭독을 포함하여 연속발화를 분석할 때 항상 지적되는 문제는 객관적이고 정확한 결과를 위해 얼마나 실험에 영향을 미칠 수 있는 요인들을 잘 통제했는가 하는 것이다. 그러나 치 료를 전제로 하여 실시하는 공기역학 평가에서 환자 개인의 특 성을 배제하는 것은 환자가 평소 발화 시 공기를 어떻게 쓰는지 파악하고자 하는 평가의 타당성에 문제를 야기한다. 말 속도가 느린 화자에게 속도를 더 빨리 하도록 재촉할 수도 없고 말 속 도가 빠른 화자에게 속도를 늦추도록 통제할 수도 없다. 이러한 측면에서 볼 때 실험을 위해서는 통제해야 하나 실제로는 통제 하기 어려운 특성(본 연구에서는 말 속도)을 비슷하게 공유하는 참여자를 대상으로 추가 분석을 하여 그 결과를 비교해 본 것 도 흥미롭고 의미 있는 결과를 제시해 줄 수 있었다고 보여진다.

공기역학 평가는 평가 대상자가 발화를 얼마나 편하게 지속 할 수 있는지를 알려주는 중요한 지침을 제시한다. 평상 시 발 화를 할 때 기류를 어떻게 확보하고 활용하는지 파악하려면 연 장모음만으로는 충분한 정보를 얻기 어렵다. 공기역학 평가 시 연장모음뿐 아니라 연속발화를 분석 자료로 사용해야 함을 주 장한 연구는 많았지만(Dastolfo et al., 2016; Lewandowski et al., 2018; Maryn \& Roy, 2012; Thiel et al., 2019), 아직 국내에 서는 그 연구가 매우 적으며 정상군과 음성장애 환자군을 비교 한 연구는 더욱 적다. 본 연구는 정상군과 음성장애 환자군의 연 속발화 시 공기역학 특성을 비교하여 제시함으로써 연속발화 시 음성장애 환자의 공기역학 특성을 파악하고 음성장애 환자를 위한 평가나 중재의 효과 입증에도 활용 가능한 자료를 제시하 였다. 그러나 본 연구는 성인 여성만을 대상으로 하여 성인 남성 이나 아동 혹은 노인의 경우에는 적용하기 어렵다는 제한점을 갖고 있다. 그러므로 추후에는 남성 집단과 아동 및 노인을 대상 으로 연구가 확대되어야 할 것이다. 또한 본 연구에 참여한 음성 장애 환자들은 음성 과기능을 원인으로 하는 기능적 음성장애 환자들이다. 음성 문제를 주소로 내원하는 환자 중에는 기능적 음성장애 환자가 다수를 차지하지만 추후에는 기질적 및 신경학 적 음성장애 환자를 대상으로 한 연구도 이어져야 할 것이다.

중심 단어 : 공기역학 평가·연속발화·문단 낭독·음성장애 환자.

\section{Ethical Statement}

This study was approved by the Institutional Review Board of the Chosun University (IRB No.: 2-1041055-AB-N-01-2019-21). 


\section{Acknowledgments}

The authors thank to the participants.

\section{Declaration of Conflicting Interests}

There are no conflict of interests.

\section{Funding}

This study was supported by research fund from Chosun University, 2017.

\section{ORCID iD}

Hwa-Young Pyo

https://orcid.org/0000-0003-3697-2111

\section{REFERENCES}

Dastolfo, C., Gartner-Schmidt, J., Yu, L., Carnes, O., \& Gillespie, A. I. (2016). Aerodynamic outcomes of four common voice disorders: Moving toward disorder-specific assessment. Journal of Voice, 30(3), 301 307.

Espinoza, V. M., Zañartu, M., Van Stan, J. H., Mehta, D. D., \& Hillman, R. E. (2017). Glottal aerodynamic measures in women with phonotraumatic and nonphonotraumatic vocal hyperfunction. Journal of Speech, Language, and Hearing Research, 60(8), 2159-2169.

Gartner-Schmidt, J. L., Hirai, R., Dastolfo, C., Rosen, C. A., Yu, L., \& Gillespie, A. I. (2015). Phonatory aerodynamics in connected speech. The Laryngoscope, 125(12), 2764-2771.

Gerratt, B. R., Kreiman, J., \& Garellek, M. (2016). Comparing measures of voice quality from sustained phonation and continuous speech. Journal of Speech, Language, and Hearing Research, 59(5), 994-1001.

Han, J. Y., Lee, O. B., \& Shim, L. S. (2008). The study of breath group based on oral airflow in reading by healthy speakers. Speech Sciences, 15(4), $135-146$.

Jiang, J. J. \& Maytag, A. L. (2014). Aerodynamic measures of glottal func- tion: What extra can they tell us and how do they guide management? Current Opinion in Otolaryngology and Head and Neck Surgery, 22(6), 450-454.

Kim, H. H. (2017). Neurogenic speech and language disorder. In Sim, H. S., Kwon, M. S., Kim, S. J., Kim, Y. T., Kim, J. M., Kim, J. S., et al. Introduction to Communication Disorders. Seoul: Hakjisa.

Kim, Y. H., Ha, E. H., \& Shin, S. J. (2003). A study on the menopausal symptoms and quality of life in middle aged women. Journal of Korean Academy of Nursing, 33(5), 601-608.

Lee, H. \& Kim, S. (2017). Comparison of overall speaking rate and pause between children with speech sound disorders and typically developing children. Phonetics and Speech Sciences, 9(2), 111-118.

Lewandowski, A., Gillespie, A. I., Kridgen, S., Jeong, K., Yu, L., \& GartnerSchmidt, J. (2018). Adult normative data for phonatory aerodynamics in connected speech. The Laryngoscope, 128(4), 909-914.

Maryn, Y. \& Roy, N. (2012). Sustained vowels and continuous speech in the auditory-perceptual evaluation of dysphonia severity. Jornal da Sociedade Brasileira de Fonoaudiologia, 24(2), 107-112.

Mehta, D. D. \& Hillman, R. E. (2008). Voice assessment: Updates on perceptual, acoustic, aerodynamic, and endoscopic imaging methods. Current Opinion in Otolaryngology and Head and Neck Surgery, 16(3), 211-215.

Mills, R., Hays, C., Al-Ramahi, J., \& Jiang, J. J. (2017). Validation and evaluation of the effects of semi-occluded face mask straw phonation therapy methods on aerodynamic parameters in comparison to traditional methods. Journal of Voice, 31(3), 323-328.

Pyo, H., Kim, S., \& Baek, S. (2014). A comparison study of breath groups during reading paragraph tasks in normal adults and adult patients with voice disorders: A preliminary study. Phonetics and Speech Sciences, 6(4), 181-187.

Thiel, C., Yang, J., Crawley, B., Krishna, P., \& Murry, T. (2019). Aerodynamic characteristics of syllable and sentence productions in normal speakers. Journal of Voice, 33(3), 297-301. 


\section{APPENDIX}

\section{Reading Material}

우리나라의 가을은 참으로 아름답다. 무엇보다도 산에 오를 땐 더욱더 그 빼어난 아름다움이 느껴진다. 쓰다듬어진 듯한 완만함 과 깎아놓은 듯한 뾰족함이 어우러진 산등성이를 따라 오르다 보면 절로 감탄을 금할 수가 없게 된다. 붉은색, 푸른색, 노란색 등의 여러 가지 색깔이 어우러져 타는 듯한 감동을 주며 나아가 신비롭기까지 하다. 숲속에 누워서 하늘을 바라보라. 쌍쌍이 짝지어 있는 듯한 흰 구름, 높고 파란 하늘을 쳐다보고 있노라면 과연 옛부터 가을을 천고마비의 계절이라 일컫는 이유를 알게 될 것만 같다. 